\title{
ANALISIS MAKNA REFERENSIAL PADA RUBRIK PENDIDIKAN DALAM SURAT KABAR JAMBI EKSPRES EDISI BULAN MARET 2017
}

\author{
Reski Kurniawan ${ }^{1}$, Sumiharti ${ }^{2}$, Firman Tara ${ }^{3}$ \\ Program Studi Pendidikan Bahasa dan Sastra Indonesia, \\ Fakultas Keguruan dan Ilmu Pendidikan, Universitas Batanghari, \\ Jambi \\ Kurniawanr28@yahoo.com \\ harti.sumi@yahoo.com \\ firmantara14@gmail.com
}

\begin{abstract}
This research is aimed at describing the meaning and total meaning of referential meaning that is used in educational rubric in the newspaper Jambi EkspresMarch edition 2017. This research is qualitatve descriptive. The function of this method is to simplify and to solve things with empiric evidence. The subject of this research is education rubric which is taken randomly by using simple random sampling. The data is collected by using libarary study and documentation technique. The data is analyzed by using steps, they are data reduction, data serving, data triangulation, and conclusion. The result of the analysis shows that there 14 quotes of referential meaning in the education rubric in Jambi Ekspresnewspaper March 2017 edition. .
\end{abstract}

Key Words: referential meaning, education rubric, jambi ekspress

\footnotetext{
${ }^{1}$ Mahasiswa Program Studi Pendidikan Bahasa dan Sastra Indonesia, Fakultas Keguruan dan Ilmu Pendidikan, Universitas Batanghari, Jambi

${ }^{2}$ Dosen Program Studi Pendidikan Bahasa dan Sastra Indonesia, Fakultas Keguruan dan Ilmu Pendidikan, Universitas Batanghari ,Jambi

${ }^{3}$ Dosen Program Studi Pendidikan Bahasa dan Sastra Indonesia, Fakultas Keguruan dan Ilmu Pendidikan, Universitas Batanghari, Jambi
} 


\section{PENDAHULUAN}

Setiap orang memerlukan sarana untuk menyampaikan pesan dalam berkomunikasi,. Sarana yang paling utama untuk memenuhi kebutuhan tersebut ialah bahasa. Setiap anggota masyarakat dan komunitas selalu terlibat dalam komunikasi bahasa, baik bertindak sebagai komunikator maupun sebagai komunikan. Anggota masyarakat sebagai partisipan bahasa tersebut, berkomunikasi sosial melalui wacana lisan dan tulis.

Wacana merupakan tataran yang paling besar dalam aspek kebahasaan. Untuk wacana yang disampaikan secara tertulis, penyampaian informasi disampaikan secara tertulis. Ini dimaksudkan agar tulisan tersebut dapat oleh pembaca. Begitu juga sebaliknya wacana lisan, penyampaian informasi disampaikan secara lisan. Ini dimaksudkan agar informasi yang disampaikan dapat disimak oleh pendengar.

Dalam hal ini, wacana tulis lebih diminati oleh anggota masyarakat dalam mendapatkan informasi dikarenakan untuk mendapatkan pemahaman yang akan dicapai dapat dilakukan secara berulang-ulang yaitu dengan cara membacanya. Hubungan antarkalimat dalam sebuah wacana tulis tersusun berkesinambungan dan membentuk suatu kepaduan. Oleh karena itu, kepaduan makna dan kerapian bentuk pada wacana tulis merupakan salah satu faktor yang penting dalam rangka meningkatkan tingkat kepahaman para pembaca.

Sama halnya dengan bahasa yang digunakan wacana dalam surat kabar, memegang peran penting dalam penulisannya. Artinya bagaimana menuliskan bahasa yang tepat dalam surat kabar ini untuk membantu para penikmat surat kabar memahami makna yang disampaikan dalam surat kabar tersebut perlu diperhatikan secara seksama. Salah satunya adalah mengenai bahasa referensial. Bisa kita bayangkan jika penggunaan referensial dalam surat kabar tidak tepat penggunaannya, maka akan banyak sekali pengguna jasa surat kabar yang akan bingung memahami makna yang disampaikan dalam surat kabar tersebut, mengingat surat kabar adalah salah satu media massa yang berfungsi sebagai pemberi berita. 
Referensial di dalam bahasa digunakan sebagai topik baru (untuk memperkenalkan) atau untuk menegaskan bahwa topik masih sama. Topik yang sudah jelas biasanya dihilangkan atau diganti. Pada kalimat yang panjang terdapat prediket dengan subjek yang sama. Subjek hanya disebutkan satu kali pada permulaan kalimat, lalu diganti dengan acuan (referensi) yang sama. Penggunaan referensial dalam surat kabar juga digunakan dalam rubrik, salah satunya adalah rubrik pendidikan. Penggunaan referensial dalam surat kabar khususnya pada rubrik pendidikan sangat perlu diperhatikan. Jika subjek diulang dengan kata yang sama sebanyak tiga kali dalam rangkaian kalimat, tentu saja akan membingungkan pembacanya sehingga pembaca tidak akan dapat menangkap makna yang dimaksud dalam rubrik tersebut.

\begin{tabular}{ccc}
\multicolumn{2}{c}{ Peneliti memilih berita } \\
pendidikan sebagai objek dalam
\end{tabular} penelitian dengan alasan bahwa rubrik pendidikan merupakan salah satu objek yang paling ditunggu-tunggu. Rubrik pendidikan biasanya dimuat hampir pada setiap periode dikarenakan rubrik pendidikan merupakan topik yang sangat familiar bagi setiap masyarakat. Maka dari itu dalam penyampaiannya sangat perlu diperhatikan penggunaan referensial agar makna yang disampaikan dalam surat kabar ini dapat dipahami. Adapun surat kabar yang akan digunakan sebagai media dalam penelitian ini adalah surat kabar Jambi Ekspress.

Surat kabar Jambi Ekspress ini merupakan salah satu surat kabar terbesar yang ada di Kota Jambi, tentu saja memiliki banyak pelanggan yang akan membacanya setiap hari. Dikarenakan rubrik pendidikan dalam surat kabar dimuat hampir pada semua periode, maka dari itu penulis memfokuskan pada surat kabar yang diterbitkan pada edisi bulan Maret 2017 yang merupakan periode kelulusan baik tingkat sekolah dasar, menengah pertama dan menengah atas.

Adapun fokus permasalahan dalam penelitian ini adalah hanya mengkaji makna dan jumlah referensial yang terdapat dalam rubrik pendidikan pada surat kabar Jambi Ekspress edisi bulan Maret 2017.

Berdasarkan fokus penelitian di atas maka pertanyaan penelitian ini adalah "Bagaimanakah makna referensial yang terdapat dalam rubrik pendidikan 
pada surat kabar Jambi Ekspress edisi Maret 2017?". Sejalan dengan pertanyaan penelitian tersebut, maka penelitian ini bertujuan untuk mendeskripsikan makna referensial yang digunakan dalam rubrik pendidikan pada surat kabar Jambi Ekspress edisi Bulan Maret 2017.

Bahasa dapat dikatakan mewakili bentuk komunikasi. Hal ini seperti yang diungkapkan Widjaja menyatakan bahwa "Komunikasi adalah hubungan kontak antar dan antara manusia baik individu maupun kelompok." Sedangkan menurut Albig dalam Widjaja (1997:15) "Komunikasi adalah proses pengoperan lambinglambang yang berarti bagi individuindividu." Artinya komunikasi adalah pernyataan manusia yang dapat dilakukan dengan kata-kata tertulis ataupun lisan.

Berdasarkan media yang digunakan, ragam bahasa dibedakan atas ragam bahasa lisan dan ragam bahasa tulis. "Ragam bahasa lisan ditandai dengan penggunaan lafal atau pengucapan, intonasi, kosa kata, penggunaan tata bahasa dalam pembentukan kata, dan penyusunan kalimat" (Widjono, 2007:23), sedangkan
"Ragam bahasa tulis ditandai dengan kecermatan menggunakan ejaan dan tanda baca, kosa kata, penggunaan tata bahasa dalam pembentukan kata, penyusunan kalimat, paragraf dan wacana" (Widjono, 2007:23).

Semantik adalah sebuah penelitian makna pada kata. Hal ini selaras dengan apa yang diungkapkan Slametmujana dalam Djajasudarma (2009:22) "Semantik adalah dalam arti bagaimana kata itu muncul, bagaimana perkembangannya, dan mengapa terjadi perubahan makna dalam sejarah bahasa)."

Dikatakan makna referansial bila sebuah kata mempunyai referen yaitu sesuatu di luar bahasa yang diacu oleh kata tersebut (Chaer, 1990:66). Artinya kata-kata yang termasuk kata penuh adalah kata-kata yang bermakna referensial. Bentuk kebahasaan memiliki hubungan dengan konsep dalam pikiran manusia yang disebut makna (sense) dan konsep ini lazimnya berhubungan dengan sesuatu atau hal yang ada di luar bahasa yang disebut referen (referent).

Surat kabar merupakan penerbitan yang berupa lembaga yang berisi beritaberita karangan. Berita-berita tersebut berisi mengenai kejadian-kejadian politik, pemerintahan, ekonomi, serta pendidikan. Seperti yang diungkapkan Widarmanto 
(2015:15) "Dalam peradaban umat manusia, surat kabar merupakan media massa cetak paling tua dibandingkan media massa cetak lainnya, seperti buku, majalah dan tabloid.”

Surat kabar tidak hanya berisi tentang berita-berita yang menjurus pada keilmiahan, tetapi juga terdapat hiburan. Hal ini sesuai dengan pendapat Kusumaningrat (2012:15) "Surat kabar juga biasanya berisi kartun, TTS, dan hiburan lainnya." Artinya di dalam surat kabar berisi tentang segala hal yang mampu memuaskan hati masyarakat baik menerima informasi ilmiah maupun hiburan.

Arti penting surat kabar terletak pada kemampuannya untuk menyajikan berita-berita atau gagasan-gagasan tentang perkembangan masyarakat pada umumnya. Sehingga hampir sebagian masyarakat menggantungkan dirinya untuk berlangganan surat kabar guna memperoleh informasi. Surat kabar berkembang sangat pesat sesuai perkembangan zaman. Di provinsi Jambi, surat kabar yang menjadi salah satu favorit masyarakatnya yaitu surat kabar Jambi Ekspress.

\section{METODE PENELITIAN}

Jenis penelitian penulis yaitu penelitian kualitatif. Dalam suatu penelitian memerlukan metode untuk mencapai tujuan yang diharapkan. "Metode penelitian pada dasarnya merupakan cara ilmiah untuk mendapatkan data dengan tujuan dan kegunaan tertentu" (Sugiyono, 2013:2). Metode yang digunakan dalam penelitian ini yaitu metode deskriptif. Menutut Djajasudarma (2010:9) beliau mengemukakan "Metode deskriptif adalah metode yang bertujuan membuat deskripsi maksudnya membuat gambaran, lukisan secara sistematis, factual, dan akurat mengenai data, sifat-sifat serta hubungan fenomena-fenomena yang diteliti."

Penelitian kualitatif ditekankan pada deskripsi. "Penelitian kualitatif ditekankan pada deskripsi objek yang diteliti” (Berg dalam Muhammad, 2011:30). "Penelitian kualitatif dilakukan dengan tidak mengutamakan pada angkaangka, tetapi mengutamakan kedalam penghayalan terhadap interaksi antar konsep yang sedang dikaji secara empiris" (Semi, 2012:28). Penelitian kualitatif lebih menekankan pada pemaknaan dan interpretasi. Maka dari itu, peran peneliti menjadi sangat penting untuk membuat suatu deskripsi tentang fenomena yang sesuai dengan konteks.

Berdasarkan uraian di atas, pendekatan dalam penelitian ini yaitu 
pendekatan kualitatif sebagai prosedur dalam memecahkan masalah. Peneliti dapat menyimpulkan bahwa penelitian deskriptif kualitatif adalah penelitian yang berfungsi untuk menyederhanakan serta memecahkan masalah yang ada secara apa adanya dengan data yang empiris.

Sumber data adalah subjek darimana dapat diperoleh (Arikunto, 2010:172). Sumber data dalam penelitian ini yaitu berupa surat kabar Jambi Ekspress berupa berita Pendidikan. Selain surat kabar Jambi-Ekspress, sumber data lainnya yaitu berbagai perpustakaan seperti perpustakaan Fakultas Keguruan dan Ilmu Pendidikan, perpustakaan Universitas Batanghari, perpustakaan Wilayah dan lain sebagainya.

Teknik pengumpulan data merupakan cara-cara yang digunakan peneliti dalam mengumpulkan data. Biasanya teknik pengumpulan data dipilih sesuai dengan tujuan dan focus masalah dalam sebuah penelitian, sehingga mempermudah peneliti dalam mengumpulkan data yang diperlukan.

Menurut Sugiyono (2013:224) "Teknik pengumpulan data merupakan langkah yang paling strategis dalam penelitian, karena tujuan utama dari penelitian adalah mendapatkan data." Adapun langkah-langkah mengumpulkan data dalam penelitian ini adalah sebagai berikut : (1) Studi pustaka, teknik ini digunakan untuk mencari bukubuku atau teori-teori mengenai makna referensial, rubrik pendidikan, ataupun literatur lain yang erat kaitannya dengan penelitian ini. (2) Dokumentasi, digunakan untuk mengumpulkan data-data penelitian pada rubrik pendidikan dalam surat kabar Jambi Ekspress edisi Maret 2017. (3) Penulis menandai data dengan menggarisi kata menggunakan pensil warna dan mencatat bagian-bagian makna referensial dalam rubrik pendidikan surat kabar Jambi Ekspress edisi Maret 2017. (4) Setelah data terkumpul, peneliti kemudian mengklasifikasikan data sesuai dengan makna referensial.

Menurut Sugiyono

$(2013: 244)$

"Analisis data adalah proses mencari dan menyusun secara sistematis data yang diperoleh dari hasil wawancara, catatan lapangan dan dokumentasi dengan cara mengorganisasikan data ke dalam kategori, menjabarkan ke dalam unit-unit, melakukan sintesa, menyusun ke dalam pola, memilih mana yang penting dan yang akan dipelajari dan membuat kesimpulan sehingga mudah dipahami oleh diri sendiri maupun orang lain."

Analisis data dalam penelitian ini bersifat deskriptif kualitatif. Hal ini 
dikarenakan objek yang diteliti berupa data-data yang memerlukan penjelasan secara deskriptif. Adapun kegiatan menganalisis data dalam penelitian ini seperti yang diungkapkan oleh Miles and Huberman dalam Sugiyono (2013:246).

Pertama, reduksi data, langkah awal penulis menganalisis data, yaitu penulis melakukan reduksi data. Dalam mereduksi data, penulis berpijak pada sebuah tujuan. Tujuan utama penelitian ini yaitu menganalisis penggunaan makna referensial dalam berita pendidikan pada surat kabar Jambi Ekspress edisi Maret 2017. Berita yang ada di surat kabar Jambi-Ekspress tersebut, penulis memberikan kode pada masing-masing berita. Pengkodean ini diberikan agar dalam menganalisis masing-masing berita tersebut akan lebih mudah. Karena berita pendidikan pada surat kabar ini hampir setiap harinya dimuat. Untuk lebih mudah lagi, penulis mencantumkan data-data yang didapat ke dalam tabel.

Kedua, penyajian data, setelah data direduksi. Langkah selanjutnya, yaitu penyajian data yang dilakukan dalam bentuk uraian singkat. Artinya data yang telah direduksi dalam tabel, kemudian dideskripsikan secara jelas supaya dapat dimengerti orang lain. Ketiga, triangulasi data, dalam hal ini mengeni keabsahan data penulis berkonsultasi dengan pembimbing, teman-teman yang telah selesai studi, serta teman-teman yang sedang menyelesaikan skripsi. Keempat, penarikan kesimpulan, langkah selanjutnya yaitu penarikan kesimpulan dengan tujuan menjawab pertanyaan penelitian yang telah dirumuskan di awal.

\section{HASIL DAN PEMBAHASAN}

Pada bagian ini penulis menyajikan hasil analisis makna referensial pada rubrik pendidikan dalam surat kabar Jambi Ekspres edisi Maret 2017. Subjek dalam penelitian ini berupa rubrik pendidikan edisi Maret 2017. Jumlah makna referensial dalam kutipan rubrik pendidikan tersebut yaitu sebanyak 14 kutipan. Rubrik pendidikan tersebut diberi kode RP01 Rubrik pendidikan.

Pada rubrik pendidikan kode RP01 terdapat makna referensial pada 14 kutipan yaitu sebagai berikut.

1.1 Hari pertama ujian sekolah berstandar nasional USBN berlangsung di 36 SMA. (RP01)

1.2 Ribuan peserta mengerjakan soal ujian berbasis komputer. (RP01)

1.3 Sejumlah komputer tiba-tiba log out. (RP01)

1.4 Panic karena komputer tiba-tiba blank, kata Irma Herawati seorang siswa SMAN 1 Kebomas. (RP01)

1.5 Nah, di tengah konsentrasi mengerjakan soal esai, komputernya mendadak logout. (RP01) 
1.6 Irma pun meminta bantuan proctor agar komputer bisa diaktifkan kembali. (RP01)

1.7 Ternyata teman-teman lain mengalami hal serupa. Alhamdulillah, komputer aktif lagi. (RP01)

1.8 Proktor utama Jaenuri mengakui bahwa sebagian besar masalah terjadi karena komputer siswa logout. (RP01)

1.9 Untunglah, siswa yang komputernya blank tidak sampai mengulang mengerjakan soal. (RP01)

1.10 Setelah diperiksa, permasalahan tersebut dipicu pemasangan kabel local area network (LAN) yang tidak sinkron dengan jaringan internet dan client. (RP01)

1.11 Penyebabnya mungkin kabel tertukar. (RP01)

1.12 Namun, dia tidak membantah temuan kendala di sejumlah sekolah. (RPO1)

1.13 Sebab, setiap sekolah memiliki proktor yang stand by. (RP01)

1.14 Hari ini diujikan mata pelajaran biologi bagi jurusan IPA, geografi untuk IPS, dan antropologi di jurusan bahasa. (RP01)

Pembahasan penelitian ini berupa pendeskripsian makna referensial yang terdapat dalam rubrik pendidikan edisi Maret 2017. Berdasarkan hasil penelitian yang telah dikemukakan dapat dijabarkan bahwa dalam rubrik pendidikan edisi Maret 2017 ini terdapat 14 kutipan yang terdapat makna referensial di dalamnya. Pembahasan penelitian ini berupa pendeskripsian makna referensial yang terdapat dalam rubrik pendidikan edisi Maret 2017.

\section{SIMPULAN}

Berdasarkan hasil penelitian dan pembahasan yang telah dijabarkan pada bab sebelumnya mengenai makna referensial dan jumlah makna referensial, maka dapat disimpulkan bahwa rubrik pendidikan edisi Maret 2017 ini terdapat makna referensial pada rubrik pendidikan. Rubrik pendidikan 01 (RP01) sebanyak 14 kutipan yang terdapat makna referensial. Salah satu contohnya "Setelah diperiksa, permasalahan tersebut dipicu pemasangan kabel local area network (LAN) yang tidak sinkron dengan jaringan internet dan client."katakabel mempunyai referen yaitu rakitan aliran listrik.

\section{DAFTAR PUSTAKA}

Arikunto, Suharsimi. (2010). Prosedur Penelitian Suatu Pendekatan Praktik. Jakarta:Rineka Cipta.

Chaer, Abdul. (1990). Pengantar Semantik Bahasa Indonesia. Jakarta: Rineka Cipta.

Djajasudarma, Fatimah. (2009). Semantik 2, Pemahaman Ilmu Makna. Jakarta: PT. Refieka Aditama.

Muhammad. (2011). Metode Penelitian Bahasa. Jogjakarta: Arruz Media.

Semi, M. Atar. (2012). Dasar-Dasar Penelitian. Bandung: Angkasa.

Analisis Makna Referensial pada Rubrik Pendidikan dalam Surat Kabar Jambi Ekspres Edisi Bulan Maret 2017 
Sugiyono. (2013). MetodePenelitian Kuantitatif Kualitatif dan $R \& D$. Bandung: Alfabeta.

Widarmanto. (2015). Surat Kabar Indonesia. Jakarta: Gramedia Pustaka.
Widjaja, H.A.W. (1997). Komunikasi:

Komunikasi dan Hubungan Masyarakat. Jakarta: Bumi Aksara.

Widjono, H.S. (2007). Bahasa Indonesia.

Jakarta: PT. Grasindo. 